\title{
Sjef Houppermans, Samuel Beckett \& Compagnie
}

\section{Emanuele Kanceff}

\section{(2) OpenEdition}

\section{Journals}

\section{Edizione digitale}

URL: https://journals.openedition.org/studifrancesi/39743

DOI: 10.4000/studifrancesi.39743

ISSN: 2421-5856

\section{Editore}

Rosenberg \& Sellier

\section{Edizione cartacea}

Data di pubblicazione: 1 décembre 2004

Paginazione: 407

ISSN: 0039-2944

\section{Notizia bibliografica digitale}

Emanuele Kanceff, «Sjef Houppermans, Samuel Beckett \& Compagnie», Studi Francesi [Online], 143 (XLVIII | II) | 2004, online dal 30 novembre 2015, consultato il 19 mai 2021. URL: http://

journals.openedition.org/studifrancesi/39743 ; DOI: https://doi.org/10.4000/studifrancesi.39743

Questo documento è stato generato automaticamente il 19 mai 2021.

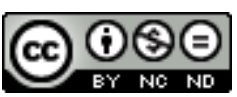

Studi Francesi è distribuita con Licenza Creative Commons Attribuzione - Non commerciale - Non opere derivate 4.0 Internazionale. 


\title{
Sjef Houppermans, Samuel Beckett \& Compagnie
}

\author{
Emanuele Kanceff
}

\section{NOTIZIA}

SJEF HOUPPERMANS, Samuel Beckett \& Compagnie, Amsterdam-New York, Rodopi, 2003

(«Faux titre», 235), pp. 153.

Questo libro originale porta in copertina una vecchia fotografia di gruppo, che mostra Beckett attorniato da una "compagnia" di intellettuali: niente di meglio si poteva trovare per dare una definizione visiva e immediata dell'opera, che finisce con l'essere la storia di una messe copiosa di relazioni individuali e spirituali, di cui lo scrittore è al centro ideale nella parabola di una ricerca infinita, attraverso i testi, il teatro, il ricordo, la lettura. Di questa strana compagnia fanno parte anche Marcel Proust, Claude Simon, Robert Pinget, Christian Oster, Gilles Deleuze. 